\title{
PENGARUH PENGETAHUAN POLITIK TERHADAP TINGKAT PARTISIPASI POLITIK MAHASISWA PADA PEMILIHAN PRESIDEN TAHUN 2019-2024
}

\author{
A. Aco Agus ${ }^{1}$, Sukri Badaruddin², Mirwan Fikri Muhkam² ${ }^{3}$, Aprilia Dwi Umalia ${ }^{4}$ \\ Email: a.aco.agus@unm.ac.id. Universitas Negeri Makassar ${ }^{1}$ \\ Email: sukribadaruddin@ stainmajene.ac.id. STAIN Majene ${ }^{2}$ \\ Email: mirwanmuhkam@gmail.com. IAIN Bone ${ }^{3}$ \\ Email: aprilia.du@gmail.com. Universitas Negeri Makassar ${ }^{4}$
}

\begin{abstract}
ABSTRAK: Penelitian ini bertujuan untuk mengetahui pengaruh pengetahuan politik terhadap partisipasi politik mahasiswa PPKn Fakultas Ilmu Sosial Universitas Negeri Makassar pada pemilihan presiden tahun 2019-2024. Penelitian menggunakan pendekatan kuantitatif. Berdasarkan sumbernya, jenis data dalam penelitian ini bersifat kuantitatif yang diperoleh melalui metode kuesioner, dokumentasi dan wawancara terhadap mahasiswa yang aktif di Jurusan Pendidikan Pancasila dan Kewarganegaraan, kemudian diolah dan disajikan secara deskriptif. Hasil penelitian menunjukkan bahwa terdapat pengaruh positif antara pengetahuan politik terhadap partisipasi politik, namun pengaruh positif yang diberikan pengetahuan politik terhadap partisipasi politik Mahasiswa PPKn FIS UNM pada Pemilihan Presiden tahun 2019-2024 hanya sebesar 23\%. Hal ini ditunjukkan dengan koefisien korelasi $\left(\mathrm{r}_{\mathrm{x} 1 \mathrm{y}}\right)$ sebesar 0,488 dan koefisien determinan $\left(\mathrm{r}^{2}{ }_{\mathrm{x} 1 \mathrm{y}}\right)$ sebesar 0,238. 2) serta $\mathrm{t}$ hitung 4,878 lebih besar dari t tabel sebesar $1,66462(4,8783>1,6646)$ pada taraf signifikansi $5 \%$ serta model regresi sederhana yang terbentuk adalah $\mathrm{Y}=0,395 \mathrm{X}_{1}+13,570$.
\end{abstract}

\section{KATA KUNCI: Pendidikan Karakter, Kearifan Lokal, Peserta Didik}

ABSTRACT: This research aims to determine the influence of political knowledge on the political participation of students of PPKn Faculty of Social Sciences, Makassar State University in the 2019-2024 presidential election. The research uses a quantitative approach. Based on the source, the type of data in this study is quantitative obtained through questionnaire methods, documentation and interviews of students who are active in the Department of Education Pancasila and Citizenship, then processed and presented descriptively. The results showed that there is a positive influence between political knowledge and political participation, but the positive influence given by political knowledge on the political participation of PPKn FIS UNM Students in the 2019-2024 Presidential Election is only $23 \%$. This is indicated by a correlation coefficient (rx1y) of 0.488 and a determinant coefficient ( $2 x 1 y)$ of 0.238 . 2) and t count 4,878 greater than the table $t$ of $1.66462(4.8783>1.6646)$ at the level of significance $5 \%$ and the simple regression model formed is $\mathrm{Y}=0.395 \mathrm{X} 1+13.570$.

KEYWORDS: Character Education, Local Wisdom, Students 


\section{PENDAHULUAN}

Negara Indonesia adalah negara demokrasi dimana kedaulatan berada ditangan rakyat $^{1}$. Keikutsertaan Warga Negara Indonesia (WNI) dalam pemilihan umum merupakan salah satu wujud dari tanggungjawab mereka dalam kehidupan berbangsa dan bernegara, serta bentuk partisipasi politik paling minimal sebagai warga negara. Partisipasi politik dalam sebuah negara adalah hal yang substansial. Salah satu indikator kualitas demokrasi ditentukan oleh tinggi dan rendah serta bagaimana partisipasi tersebut dilakukan.

Herbert

McClosky

mengemukakan bahwa partisipasi politik adalah kegiatan-kegiatan sukarela dari warga masyarakat melalui mana mereka mengambil bagian dalam proses pemilihan penguasa, dan secara langsung atau tidak langsung, dalam proses pembentukan kebijakan umum. $^{2}$

Kesadaran politik warga negara menjadi faktor determinan dalam partisipasi politik masyarakat, artinya berbagai hal yang pengetahuan dan kesadaran akan hak dan kewajiban yang berkaitan dengan lingkungan masyarakat dan kegiatan politik menjadi ukuran dan kadar seseorang terlibat dalam proses partisipasi politik. Berdasarkan fenomena ini maka W. Page memberikan model partisipasi menjadi empat tipe ${ }^{3}$ antara lain yaitu

1. Apabila seseorang memiliki kesadaran politik dan kepercayaan kepada pemerintah tinggi maka partisipasi politik cenderung aktif.

2. Sebaliknya kesadaran dan kepercayaan sangat kecil maka

\footnotetext{
${ }^{1}$ UUD NRI Tahun 1945

2 Budiardjo, Miriam. 2008. Dasar-dasar Ilmu Politik. Edisi Revisi. Jakarta: PT Gramedia Pustaka Utama. Hal.367
}

partisipasi politik menjadi pasif dan apatis.

3. Kesadaran politik tinggi tetapi kepercayaan terhadap pemerintah lemah maka perilaku yang muncul adalah militant radikal.

4. Kesadaran politik rendah tetapi kepercayaan pada pemerintah tinggi maka partisipasinya menjadi sangat pasif, artinya hanya berorientasi pada output politik

Menurut Surbakti membedakan tipe partisipasi masyarakat ke dalam empat macam, yaitu:

a. Partisipasi Aktif

Kegiatan warga negara yang senantiasa menampilkan perilaku tanggap (responsif) terhadap berbagai tahapan kebijakan pemerintah atau dengan kata lain apabila seseorang memiliki kesadaran politik dan kepercayaan kepada pemerintah yang tinggi, maka partisipasi politik cenderung aktif.

b. Partisipasi Militan-Radikal

Kegiatan warga negara yang senantiasa menampilkan perilaku tanggap (responsif) terhadap berbagai kebijakan pemerintah. Namun berbeda dari partisipasi aktif, yang cenderung mengutamakan cara-cara konvensional, partisipasi ini cenderung mengutamakan cara-cara non konvensional, termasuk di dalamnya cara-cara kekerasan atau dengan kata lain apabila kesadaran politik tinggi tetapi kepercayaan kepada pemerintah sangat rendah, maka akan melahirkan militan radikal.

c. Partisipasi Pasif

Kegiatan warga negara yang menerima/menaati begitu saja segala kebijakan pemerintah. Jadi, partisipasi pasif cenderung tidak memersoalkan apapun kebijakan politik yang dibuat

3 Rahman. 2007. Sistem Politik Indonesia: Yogyakarta: Graha Ilmu. Hal 289 
pemerintah atau dengan kata lain apabila kesadaran politik sangat rendah tetapi kepercayaan kepada pemerintah sangat tinggi, maka akan melahirkan partisipasi yang tidak aktif (pasif).

d. Partisipasi Apatis

Kegiatan warga negara yang tidak mau tahu dengan apapun kebijakan publik yang dibuat oleh pemerintah. Umumnya, warga masyarakat bertindak demikian karena merasa kecewa dengan pemerintah dan sistem politik yang ada atau dengan kata lain apabila seseorang tingkat kesadaran politik dan kepercayaan kepada pemerintah rendah, maka partisipasi politik cenderung pasiftertekan (apatis) ${ }^{4}$

$\begin{array}{ccc}\text { Salah } & \text { satu faktor } & \begin{array}{r}\text { yang } \\ \text { politik }\end{array} \\ \text { mempengaruhi } & \text { perilaku } & \text { politik. } \\ \text { masyarakat yaitu pengetahuan } & \text { politik }\end{array}$ masyarakat yaitu pengetahuan politik memberikan pendidikan politik yang dilakukan dengan cara sosialisasi politik oleh lembaga, partai, ataupun tokohtokoh yang ada dalam masyarakat. Beberapa faktor yang mempengaruhi pengetahuan politik masyarakat, seperti tingkat pendidikan, pekerjaan, usia, agama, lingkungan pergaulan, serta media massa yang digunakan oleh masyarakat. Menurut Andriyus keikutsertaan masyarakat dalam proses pemilihan umum tidak terlepas dari adanya beberapa faktor yang mempengaruhi, adapun faktor-faktor yang mempengaruhi pemilihan umum yaitu faktor internal meliputi, tingkat pendidikan, tingkat ekonomi, dan kesadaran politik. Sedangkan untuk faktor eksternal meliputi peranan

\footnotetext{
${ }^{4}$ Yuliantina, Maya. 2016. Pengaruh Kesadaran Politik terhadap Partisipasi Politik dalam Pemilihan Kepala Desa di Desa Hajimena Kecamatan Natar Kabupaten Lampung Selatan. Universitas Lampung.

${ }^{5}$ Andriyus, (2013), Kajian Ilmu Pemerintahan : Faktor-Faktor yang Mempengaruhi Partisipasi Politik Masyarakat pada Pemilihan Umum
}

pemerintah, peranan partai politik, peranan media massa, dan perilaku calon legislatif. $^{5}$

Jason Barabas, dkk menjelaskan tentang Pengetahuan Politik Dalam jurnal "The Question(s) of Political Knowledge" dimana "political knowledge is a central concept in the study of publik opinion and political behavior". Pengetahuan politik merupakan konsep sentral dalam studi opini publik dan perilaku politik. Pengetahuan politik merupakan dasar dari perilaku politik seseorang, hal ini dapat dijelaskan dalam prespektif behavior dan pendekatan psikologis. Menurut Outhwaite dalam Nugraheni (2017) secara sederhana perilaku dapat diartikan sebagai "setiap tindakan manusia yang dapat dilihat" 6

Pengetahuan dan pemahaman tentang politik dapat diperoleh dari sosialisasi politik. Sosialisasi politik adalah suatu proses yang dilalui seseorang dalam memperoleh sikap dan orientasi terhadap fenomena politik yang ada dalam masyarakat tempat orang itu berada. Sosialisasi politik juga mencakup proses penyampaian norma-norma dan nilai-nilai dari satu generasi ke generasi berikutnya.

Fungsi sosialisasi politik itu sangat penting sebab sosialisasi politik meningkatkan pengetahuan politik dan pemahaman masyarakat tentang kehidupan politik yang pada gilirannya dapat mendorong tumbuhnya partisipasi secara maksimal dalam sistem politiknya

Pendapat lain tentang faktor yang mempengaruhi partisipasi politik juga

Legislatif 2009 di Kecamatan Singingi Hilir Kabupaten Kuantan Singingi, 2 (2), 29-34

6 Nugraheni, Ardhita Yuliana. 2017. Pengaruh Pengetahuan Politik Dan Aktor Politik terhadap Partisipasi Politik Masyarakat Desa Trimurti, Srandakan Bantul, pada Pilkada 2015. Universitas Negeri Yogyakarta.hal 31. 
disampaikan oleh Surbakti. Beliau menjelaskan bahwa faktor-faktor yang diperkirakan mempengaruhi tinggi rendahnya partisipasi politik seseorang ialah kesadaran politik dan kepercayaan kepada pemerintah (sistem politik). ${ }^{7}$ Surbakti menjelaskan yang dimaksud kesadaran politik ialah kesadaran akan hak dan kewajiban sebagai warga negara. Hal ini menyangkut pengetahuan seseorang tentang lingkungan masyarakat dan politik, dan menyangkut minat dan perhatian seseorang terhadap lingkungan masyarakat dan politik tempat dia hidup. Sikap dan kepercayaan kepada pemerintah ialah penilaian seseorang terhadap pemerintah. Kedua faktor tersebut bukan faktor-faktor yang berdiri sendiri (bukan variabel yang independen). Artinya, tinggi rendah kedua faktor itu dipengaruhi oleh faktorfaktor lain, seperti status sosial dan status ekonomi, afiliasi politik orang tua dan pengalaman berorganisasi. Status sosial ialah kedudukan seseorang dalam masyarakat karena keturunan, pendidikan, dan pekerjaan.

Sejalan dengan pendapat Miriam Budiardjo menjelaskan bahwa partisipasi politik erat kaitanya dengan kesadaran politik, karena semakin sadar bahwa dirinya diperintah, orang kemudian menuntut diberikan hak bersuara dalam penyelenggaraan pemerintah $^{8}$. Perasaan sadar seperti ini dimulai dari orang yang berpendidikan, yang kehidupannya lebih baik, dan orang-orang terkemuka. Miriam Budiardjo juga menjelaskan, di negaranegara demokrasi umumnya menganggap bahwa lebih banyak partisipasi masyarakat, akan lebih baik. Dalam alam pikiran ini tingginya tingkat partisipasi menunjukkan bahwa warga mengikuti dan memahami masalah politik dan ingin melibatkan diri dalam kegiatan-kegiatan

\footnotetext{
${ }^{7}$ Surbakti, Ramlan. 2010. Memahami Ilmu

Politik. Jakarta: Grasindo, 184-185
}

itu. Sebaliknya, tingkat partisipasi yang rendah pada umumnya dianggap sebagai tanda yang kurang baik, karena dapat ditafsirkan banyak warga tidak menaruh perhatian terhadap masalah kenegaraan.

Di negara-negara demokrasi umumnya menganggap bahwa lebih tinggi angka partisipasi masyarakat dalam pemilu (voter turnout) menunjukkan demokrasi pada negara tersebut sudah berjalan dengan baik dan tetap dipercaya oleh warga negara. Dalam konteks yang lain, tingginya tingkat partisipasi juga menunjukkan bahwa warga negara terlibat dalam kegiatankegiatan politik, baik yang aktif maupun yang pasif. Tingkat partisipasi yang tinggi dalam pemilu juga menunjukkan sejauh mana proses pemilu berjalan sesuai dengan prinsip-prinsip kebebasan, di mana warga negara yang memiliki hak dan kedaulatan diberi kebebasan untuk menentukan pilihannya. Sebaliknya, ada anggapan bahwa rendahnya partisipasi politik di suatu negara dianggap kurang baik bagi demokrasi karena memperlihatkan kurangnya perhatian dan kepedulian warga negara pada masalah politik.

Pesta demokrasi Pemilihan Umum dan Pemilihan Presiden menggambarkan bahwa kedaulatan berada ditangan rakyat, dimana pemerintah berasal dari rakyat, oleh rakyat dan untuk rakyat. Menurut Affan Gaffar (dalam Huda) memberikan parameter tentang sistem pemilu yang ideal untuk menghadapi Pilpres tahun 2019 diantaranya: (1) demokrasi dalam sistem pemilu implisit dapat dilakukan secara adil dan jujur, serta pemilu yang berkualitas; (2) out put pemilu harus berkualitas dan kompetitif serta akuntabilitas yang tinggi; (3) derajat keterwakilan dengan perimbangan antara pusat dan daerah; (4) peraturan

${ }^{8}$ Miriam. Opcit. Hal. 
perundang-undangan haruslah tuntas; (5) pelaksanaan pemilu bersifat praktis dan konkrit. ${ }^{9}$

Pemilihan Umum Presiden Indonesia 2019 adalah sebuah proses demokrasi untuk memilih Presiden dan Wakil Presiden Republik Indonesia periode 2019-2024. Pemilihan umum ini dimenangkan oleh pasangan Joko Widodo-Ma'ruf Amin dengan perolehan suara 55,50\%, diikuti oleh Prabowo Subianto-Sandiaga Uno dengan perolehan suara $44,50 \%$. Pemilihan ini dilaksanakan serentak dengan pemilihan umum legislatif.

Berdasarkan hasil observasi yang dilakukan oleh penulis terhadap Mahasiswa PPKn FIS UNM ada beberapa alasan yang dilontarkan seperti proses pemilihan diluar daerah asal yang seharusnya menggunakan kartu A5 tidak terlaksana dengan baik, ada beberapa orang yang mau menggunakan hak pilihnya dengan menggunkaan kartu A5, namun tidak dilayani oleh petugas TPS. Selanjutnya alasan kampung yang terlalu jauh sehingga tidak sempat untuk pulang menggunakan hak suaranya di kampung halaman, dan beberapa lainnya sadar bahwa pemilihan umum presiden ini penting untuk dilakukan, namun karena ketidaksukaan terhadap kedua calon Presiden sehingga mereka tidak menggunakan hak pilihnya.

Sejalan dengan pendapat Miriam Budiardjo bahwa perasaan sadar untuk mengikuti pemilihan umum dimulai dari orang-orang berpendidikan, maka dari itu penulis mengasumsikan bahwa Mahasiswa yang menjalankan pendidikan di Perguruan Tinggi adalah orang-orang yang berpendidikan yang paham terhadap masalah politik dan mau melibatkan diri dalam kegiatan-kegiatan kenegaraan, khususnya Mahasiswa Fakultas Ilmu Sosial Jurusan Pendidikan

\footnotetext{
${ }^{9}$ Huda Khairil. 2019. Pemilu Presiden 2019: Antara Kontestasi Politik dan Persaingan
}

Pancasila dan Kewarganegaraan Universitas Negeri Makassar, yang teleh melewati berbagai macam mata kuliah yang diperuntukkan agar nantinya Mahasiswa tersebut sadar dan tidak apatis terhadap kegiatan-kegiatan pemerintahan.

Oleh karena itu, peneliti tertarik untuk mengadakan penelitian dengan judul "Pengaruh Pengetahuan Politik terhadap Tingkat Partisipasi Politik Mahasiswa PPKn FIS UNM pada Pemilihan Umum Presiden 2019-2024”

\section{METODE}

Dalam penelitian ini menggunakan metode penelitian kuantitatif dengan pendekatan expost fact. Penelitian ex-post facto meneliti hubungan sebab-akibat yang tidak dimanipulasi atau tidak diberi perlakuan oleh peneliti. Variabel dalam penelitian ini adalah pengetahuan politik yang merupakan variabel bebas (X) dan variabel terikat (Y) partisipasi politik mahasiswa PPKn FIS UNM dalam Pemilihan Presiden 2019-2024. Peneliti memilih jurusan PPKn FIS UNM menjadi lokasi penelitian dengan alasan bahwa mahasiswa PPKn mempelajari ilmu politik dan ilmu hukum sehingga akan lebih memiliki pengatahuan tentang pemilihan umum karena lebih mendalam dipelajari dalam mata kuliah. Jumlah mahasiswa aktif di Jurusan PPKn telah memenuhi kebutuhan peneliti untuk mengambil beberapa sampel ataupun responden dalam melakukan penelitian.

Metode Pengumpulan data pada penelitian ini menggunakan teknik dokumentasi, wawancara berupa kuesioner penelitian dan skala likert. Sedangkan teknik analisis data untuk mengetahui pengaruh pendidikan politik terhadap tingkat partisipasi politik

Pemicu Perpecahan Bangsa. Seminar Nasional Hukum Universitas Negeri Semarang. Vol 4 (3). 
mahasiswa PPKn menggunakan analisis regresi sederhana.

\section{HASIL DAN PEMBAHASAN}

Pengujian hipotesis dalam penelitian ini menggunakan teknik analisis yaitu analisis regresi sederhana. Pengujian hipotesis menggunakan bantuan program komputer SPSS Statistics 23. Hipotesis yang diuji dalam penelitian ini adalah terdapat pengaruh positif Pengetahuan Politik terhadap Partisipasi Politik Mahasiswa PPKn FIS UNM pada Pemilihan Presiden tahun 2019-2024. Pengujian hipotesis ini menggunakan teknik analisis regresi sederhana. Ringkasan hasil uji hipotesis pertama dapat dilihat dalam tabel berikut:

Tabel 1. Hasil Pengujian Hipotesis

\begin{tabular}{|c|c|c|c|c|c|c|c|c|}
\hline Mod.* & rxly & r2xly & Thit & Ttabel & Rtabel & Koef. & Kons. & Keterangan \\
\hline $\mathrm{X}_{1}$ & 0,488 & 0,238 & 4,878 & 1,66462 & 0,1852 & 0,395 & 13,570 & $\begin{array}{c}\text { Positif dan } \\
\text { signifikan }\end{array}$ \\
\hline
\end{tabular}

Berdasarkan tabel hasil pengujian hipotesis diatas, maka diperoleh hasil dan penjabaran sebagai berikut:

\section{Persamaan Garis Regresi Sederhana}

Berdasarkan tabel di atas, maka persamaan regresi dapat dinyatakan dalam persamaan sebagai berikut: $\mathrm{Y}=$ $0,395 X_{1}+13,570$

Persamaan tersebut menunjukkan bahwa nilai koefisien regresi bernilai positif sebesar 0,395. Hal tersebut berarti apabila Pengetahuan Politik $\left(\mathrm{X}_{1}\right)$ naik satu satuan maka Partisipasi Politik naik sebesar 0,395 satuan.

\section{Koefisien Korelasi (r) dan Korfisien} Determinan $\left(\mathrm{r}^{2}\right)$

Hasil analisis regresi sederhana dengan satu predictor menunjukkan koefisien korelasi (r) sebesar 0,488 dengan koefisien determinasi (r2) sebesar 0,238. Koefisien determinasi menunjukkan ketepatan garis regresi. Garis regresi digunakan untuk menjelaskan proporsi dari partisipasi politik (Y) yang diterangkan oleh Pengetahuan Politik $\left(X_{1}\right)$. Hal ini berarti bahwa pengetahuan politik berpengaruh sebesar 23.\% terhadap Partisipasi Politik dan terdapat $73 \%$ faktor atau variabel lain yang kemungkinan berpengaruh terhadap partisipasi politik.

\section{Pengujian Signifikan dengan Uji t}

Pengujian signifikan dengan uji $t$ digunakan untuk mengetahui pengaruh Pengetahuan Politik $\left(\mathrm{X}_{1}\right)$ terhadap Partisipasi Politik ( Y ). Hipotesis yang diuji terdapat pengaruh positif Pengetahuan Politik terhadap Partisipasi Politik Mahasiswa PPKn FIS UNM pada pemilihan Presiden tahun 2019-2024.

Tabel 2. Dependent Variable: partisipasi

\begin{tabular}{|c|c|c|c|c|c|}
\hline \multirow[t]{2}{*}{ Model } & \multicolumn{2}{|c|}{$\begin{array}{l}\text { Unstandardized } \\
\text { Coefficients }\end{array}$} & $\begin{array}{l}\text { Standardized } \\
\text { Coefficients }\end{array}$ & \multirow[t]{2}{*}{ t. } & \multirow[t]{2}{*}{ Sig } \\
\hline & B & Std Error & Beta & & \\
\hline $\begin{array}{ll}\text { 1. } & \text { (Constant) } \\
& \text { Pengetahuan }\end{array}$ & $\begin{array}{l}13,570 \\
, 395\end{array}$ & $\begin{array}{l}4,883 \\
, 081\end{array}$ & ,488 & $\begin{array}{l}2,779 \\
4,878 \\
\end{array}$ & $\begin{array}{l}007 \\
, 000 \\
\end{array}$ \\
\hline
\end{tabular}


Berdasarkan output di atas diketahui nilai signifikansi (sig.) sebesar 0,000 lebih kecil dari probabilitas 0,05 sehingga dapat disimpulkan bahwa ho ditolak ha diterima, yang berarti bahwa ada pengaruh pengetahuan politik (X) terhadap partisipasi pemilihan (y).

Dari Hasil penelitian ini menujukkan bahwa nilai koefisien korelasi $\left(\mathrm{r}_{\mathrm{x} 1 \mathrm{y}}\right)$ sebesar 0,488 dan nilai koefisien determinasi $\left(\mathrm{r}^{2}{ }_{\mathrm{x} 1 \mathrm{y}}\right)$ sebesar 0,238 , sedangkan untuk $r_{\text {tabel }}$ sebesar 0,1852 . Hal ini menujjukan bahwa terdapat pengaruh positif Pengetahuan Politik terhadap Partisipasi Politik Mahasiswa PPKn FIS UNM pada Pemilihan Presiden tahun 2019-2024. Setelah dilakukan uji signifikansi dengan uji t diperoleh thitung sebesar 4,878 yang kemudian dibandingkan dengan nilai ttabel pada taraf signifikansi $5 \%$ yaitu sebesar 1,64662. Hal ini menunjukkan bahwa thitung $>$ ttabel $(4,878>1,64662)$ sehingga variabel Pengetahuan Politik memberikan pengaruh terhadap Partisipasi Politik.

Kesimpulan yang dapat diambil dari analisis ini adalah terdapat pengaruh positif Pengetahuan Politik dan Partisipasi Politik Mahasiswa PPKn FIS UNM pada Pemilihan Presiden tahun 2019-2024. Walaupun Pengetahuan Politik memiliki pengaruh yang positif terhadap Partisipasi Politik, namun dengan perolehan Presentase 23\% sangatlah kecil. Alasannya, pengaruh pengetahuan politik memiliki pengaruh dibawah 50\%. Hasil penelitian ini didukung oleh pendapat Surbakti (2010 :184) menyebutkan tinggi rendahnya Partisipasi Politik seseorang dipengaruhi oleh kesadaran politik dan kepercayaan kepada pemerintah (sistem politik). Kesadaran politik ialah kesadaran akan hak dan kewajiban sebagai warga Negara. Hal ini menyangkut pengetahuan seseorang tentang lingkungan masyarakat dan politik, dan menyangkut minat dan perhatian seseorang terhadap lingkungan masyarakat dan politik tempat dia hidup.

Terkait pengetahuan politik sebagai konsep sentral perilaku politik, Surbakti (2010: 187) menjelaskan pengetahuan politik melalui pendekatan psikologi sosial. Surbakti menjelaskan bahwa pendekatan psikologis sosial sama dengan penjelasan yang diberikan dalam model perilaku politik. Salah satu konsep psikologi sosial yang digunakan untuk menjelaskan perilaku untuk memiliki pada pemilihan umum berupa identifikasi partai. Konsep ini merujuk pada persepsi pemilih atas partai-partai yang ada atau keterikatan emosional pemilih terhadap partai tertentu. Konkretnya, partai yang secara emosional dirasakan sangat dekat dengannya merupakan partai yang selalu dipilih tanpa terpengaruh oleh faktorfaktor lain. Selain itu, tingkah laku psikologis menerjemahkan bahwa dalam tingkah laku politik adalah ia (manusia) bersama kepentingan, tujuan, dan motivasi yang mengakibatkan proses belajar, pemahaman, kognisi, dan simbolis.

Proses-proses pembelajaran politik behavioral sosialisasi. Ketika masyarakat memiliki pengetahuan terkait politik yang didukung oleh berbagai pemahaman, pengalaman dan kesadaran politik yang telah dimiliki maka partisipasi politik masyarakat pun menjadi lebih tinggi. Hasil penelitian ini selaras dengan penelitian sebelumnya yang dilakukan oleh Tri Hermanto (2009) mengenai "Pengaruh Tingkat Pendidikan dan Pekerjaan terhadap Partisipasi Politik dalam Pemilihan Umum (Studi korelasi di perumahan Joho Baru kabupaten Sukoharjo)". Hasil penelitian tersebut menunjukkan bahwa terdapat hubungan yang positif dan signifikan antara Tingkat Pendidikan terhadap Partisipasi Politik yang ditunjukkan dengan nilai $r_{x 1 y}$ 
sebesar 0,540 lebih besar dari $r_{\text {tabel }}$ sebesar $0,195(0,540>0,195)$ dengan taraf siginifikansi $5 \%$. Berdasarkan hasil penelitian dan pendapat tersebut, dapat disimpulkan bahwa terdapat pengaruh positif dan signifikan Pengetahuan Politik terhadap Partisipasi Politik Mahasiswa PPKn FIS UNM.

\section{PENUTUP}

Terdapat pengaruh positif antara pengetahuan politik terhadap partisipasi politik, namun pengaruh positif yang diberikan pengetahuan politik terhadap partisipasi politik Mahasiswa PPKn FIS UNM pada Pemilihan Presiden tahun 2019-2024 hanya sebesar 23\%. Hal ini ditunjukkan dengan koefisien korelasi $\left(\mathrm{r}_{\mathrm{x} 1 \mathrm{y}}\right)$ sebesar 0,488 dan koefisien determinan $\left(\mathrm{r}_{\mathrm{x} 1 \mathrm{y}}\right)$ sebesar 0,238 , serta $\mathrm{t}$ hitung 4,878 lebih besar dari t tabel sebesar $1,66462(4,8783>1,6646)$ pada taraf signifikansi 5\% serta model regresi sederhana yang terbentuk adalah $\mathrm{Y}=$ $0,395 \mathrm{X}_{1}+13,570$.

Bagi mahasiswa hendaknya berpartisipasi secara aktif dalam kegiatan politik dalam pemilihan umum misalnya mengamati proses pengambilan suara, mengawasi penghitungan suara, ataupun ikut mensosialisakan para calon. Mahasiswa perlu mencari tahu tentang bentuk partisipasi yang dilakukan oleh masyarakat serta mahasiswa hendaknya dapat lebih meningkatkan partisipasi dalam kegiatan menuangkan ide atau gagasan yang membangun guna mengsukseskan kegiatan pemilihan umum

Bagi peneliti selanjutnya yang ingin mengkaji pengaruh pengetahuan politik terhadap tingkat partisipasi politik, hendaknya untuk menambahkan berbagai aspek atau variabel dalam penelitian bisa ditambah sehingga mendapatkan temuan yang baru.
Bagi civitas akademika khususnya untuk Program Studi Pendidikan Pancasila dan Kewarganegaraan agar lebih memperdalam pengetahuan berupa konsep dan teori-teori politik sehingga mempengaruhi sikap dan praktik partisipasi politik dalam kegiatan pemilihan umum.

\section{DAFTAR PUSTAKA}

Budiarjo, Miriam. 2008. Dasar-Dasar Ilmu Politik. Jakarta: PT Gramedia Pustaka Utama.

Budianto, R. (2017). Pengaruh Pendidikan Politik Terhadap Partisipasi Masyarakat dalam Pemilu Tahun 2014 di Kelurahan Simpang Pasir Kecamatan Palaran Kota Samarinda. E-Journal Ilmu Pemerintahan, 5(1), 93-105.

Burhanuddin, Yusuf. 2008. Politik dalam Islam: Makna, Tujuan dan Falsafah. Jurnal Aqidah-Ta. Vol IV. Gramedia Pustaka Utama.

Fatwa, A. N. (2016). Pengaruh Kesadaran Politik Terhadap Partisipasi Politik Masyarakat dalam Pemilihan Bupati Tahun 2013 di Desa Sesulu Kabupaten Penajam Paser Utara. Jurnal Ilmu Pemerintahan,(Online), 4(4).

Fauzan, Almanshur, \& M. Djunaidi Ghony. 2017. Metodelogi Penelitian Kualitatif. Depok: Penerbit Ar-Ruzz media.

Gabriel A. Almond dalam Basri Seta. Pengantar Ilmu Politik. Jogjakarta: Indie Book Corner.

Marijan, Kacung. 2012. Sistem Politik Indonesia Konsolidasi Demokrasi Pasca-Orde 
Baru. Jakarta: Kencana Prenada Group.

Nana Syaodih Sukmadinata. 2011. Metode Penelitian

Pendidikan. Bandung: PT. Remaja Rosdakarya.

Nugraheni, A. Y. (2017). Pengaruh Pengetahuan Politik dan Aktor Politik Terhadap Partisipasi Politik Masyarakat Desa Trimurti, Srandakan, Bantul pada Pilkada 2015. Dapat diunduh dari: https://eprints. uny. ac. id/46434.

Pradja, Juhaya. S. 2013. Teori-Teori Politik. Bandung: CV Pustaka Setia.

Rahman, A. 2007. Sistem Politik Indonesia. Yogyakarta: Graha Ilmu.

Sarlito W, Sarwono. 2009. Pengantar Psikologi Umum. Depok: Penerbit PT. Raja Grafindo Persada.

Sugiyono. 2016. Metode Penelitian Kombinasi. Cetakan ke-8. Bandung: Alfabeta.

Sukidin. 2012. Sosiologi Politik. Bogor: Ghalia Indonesia.
Surajiyo. 2010. Filsafat Ilmu \& Perkembangan di Indonesia. Jakarta: Bumi Aksara.

Surbakti, Ramlan. 2010. Memahami Ilmu Politi. Jakarta: Grasindo

Tim Penyusun Kamus Besar Bahasa Indonesia, Kamus Besar Bahasa Indonesia (Jakarta: Balai Pustaka, 2001).

Undang-Undang Dasar Negara Republik Indonesia Tahun 1945 Undang-Undang No. 23 tahun 2003 tentang Pemilihan Umum Presiden dan wakil Presiden.

Undang-Undang No. 2 tahun 2011 tentang Partai Politik

Undang-undang No. 42 tahun 2008 tentang Pemilihan Presiden dan Wakil Presiden

Yustiningrum, R. E., \& Ichwanuddin, W. (2016). Partisipasi politik dan perilaku memilih pada Pemilu 2014. Jurnal Penelitian Politik, 12(1), 19. 